Article is available online at http://www.webio.hu/por/2003/9/4/0242

CASE REPORT

\title{
Synovial Sarcoma: a Rare Tumor of Larynx
}

\author{
Bilge BILGIC, ${ }^{1}$ Özgür METE, ${ }^{1}$ A Settar ÖZTÜRK, ${ }^{1}$ Misten DEMIRYONT, ${ }^{1}$ Nesil KELES, ${ }^{2}$ Mert BASARAN ${ }^{3}$ \\ ${ }^{1}$ Department of Pathology, ${ }^{2}$ ENT Surgery, Istanbul Medical Faculty, ${ }^{3}$ Medical Oncology Oncology Institute, \\ Istanbul University
}

Synovial sarcoma is a soft tissue sarcoma of unknown histogenesis and occurs predominantly in the lower extremities of young adults. The head and neck is a relative rare location. There are about 10 cases with laryngeal localization in the literature. We present a 24 year-old male with an endolaryngeal mass. Incisional biopsy and the hemilaryngectomy material revealed a biphasic synovial sarcoma. One year later a local recurrence occurred. Keywords: larynx, synovial sarcoma
Tumor excision and neck dissection were performed. Radiotherapy was added. Six months later lung metastases was discovered on thoracic CT. The patient received chemotherapy for 6 courses. The metastases responded well to chemotherapy and the patient is now alive without tumor on radiological and clinical examination after 3.5 years of follow-up. (Pathology Oncology Research Vol 9, No 4, 242-245)

\section{Introduction}

Synovial sarcoma is a mesenchymal malignancy of unknown histogenesis and occurs mostly in the extremities. About $9 \%$ of the cases were reported in the head and neck region. ${ }^{19}$ Involvement of the larynx is very rare. The literature includes about 10 cases of synovial sarcoma of the larynx..$^{2-4,6,7,9-14}$ Most cases were treated either with surgery alone or combined with radiotherapy. Only two cases were reported to whom chemotherapy was administered. $^{3,12}$ A laryngeal synovial sarcoma treated with surgery, radiotherapy and chemotherapy was presented and the differential diagnosis was reviewed.

\section{Case Report}

A 24 years old male patient was admitted to the ENT Department of the University Hospital complaining of changing of his voice and dysphagia for several months. Under laryngoscopic examination, an endolaryngeal mass involving epiglottis was discovered. Magnetic resonance imaging revealed a tumor which filled up the entire supra-

Received: May 6, 2003; accepted: Nov 12, 2003

Correspondence: Bilge BILGIC, Department of Pathology, Istanbul Medical Faculty, CAPA 34390 Istanbul, Turkey. Fax: 0212 6311367, e-mail: eminbilgic@superonline.com

glottic region (Figure 1). Under microlaryngoscopic procedure incisional biopsy was taken. The tumor was $1.5 \mathrm{~cm}$ in diameter and the histology was of a biphasic synovial sarcoma. Laryngectomy was planned but the patient came two months later; than a hemilaryngectomy was performed. The tumor was supraglottic in location and involved the left arytenoid and the aryepiglottic plica. The tumor measured $3 \times 2.5 \times 0.7 \mathrm{~cm}$. The surgical margins contained no tumor. One year later a local recurrence occurred. The former operation was extended to total laryngectomy. A tumor $2.5 \mathrm{~cm}$ in diameter, a thyroid nodule and cervical lymph nodes were excised. The tumor was infiltrating the surrounding soft tissue and had the same histology. The thyroid nodule and the lymph nodes contained no tumor. The surgical margins were free of tumor. Following surgery, bilateral cervicofascial and left supraclavicular radiotherapy (each $45 \mathrm{~Gy} / 25$ fraction) was given. At 20 months of follow-up bilateral lung lesions and left pleural effusion developed. The patient underwent chemotherapy consisted of adriamycin $\left(75 \mathrm{mg} / \mathrm{m}^{2}\right)$ and ifosfamide $\left(2 \mathrm{~g} / \mathrm{m}^{2}\right)$. To prevent hemorrhagic cystitis MESNA $\left(1.5 \mathrm{~g} / \mathrm{m}^{2}\right)$ was given. After 3 months regression was achieved. The patient received 6 cycles of chemotherapy at three weekly intervals. Ifosfamide was given for 3 days in every course. Radiological examination revealed no regional mass or metastatic nodules in lung at 3.5 years of follow-up. 


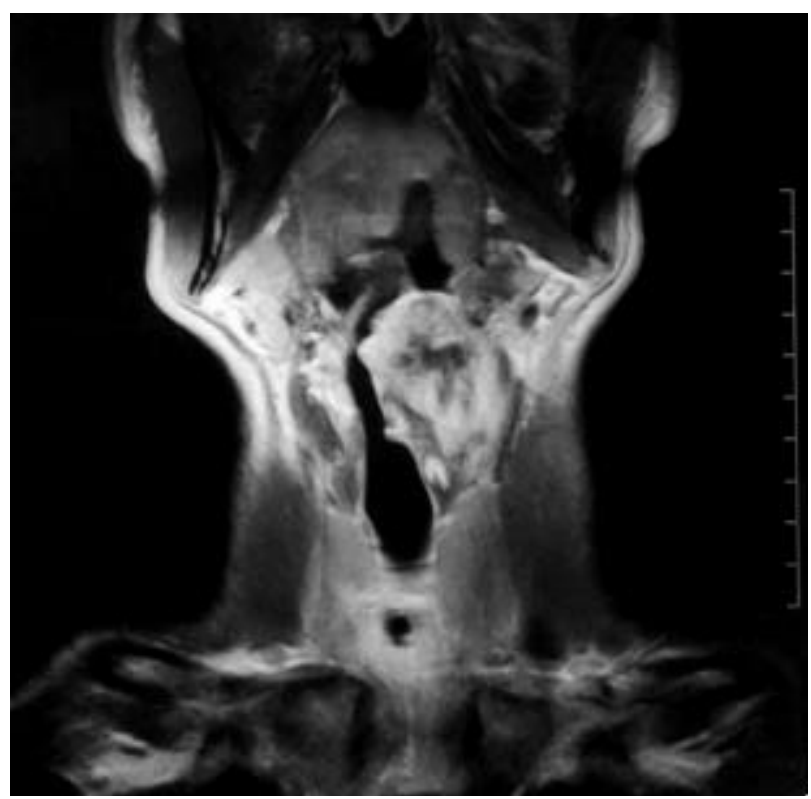

Figure 1. Radiological appearance of the tumor

\section{Microscopical and immunohistochemical findings}

The morphology was the same in all biopsy material. A biphasic tumor consisting of glandular structures and spindle cells was seen (Figure 2). Epithelial component was in the form of glands or clefts lined by cuboidal epithelial cells. In the lumina of the glands, PAS positive material was observed. The sarcomatous area was characterized by a cellular, spindle cell infiltration without any special pattern. Necrosis was $5 \%$, calcification was absent, mitotic figures were counted as 7/10HPF.

Immunohistochemistry was performed using streptavidin-biotin-peroxidase system Primary antibodies used were: cytokeratin (Pan-Ab-1, Novacastra, antigen retrieval, 1/50, 60 min.); EMA (Neomarker; 1/50, 30 min); vimentin

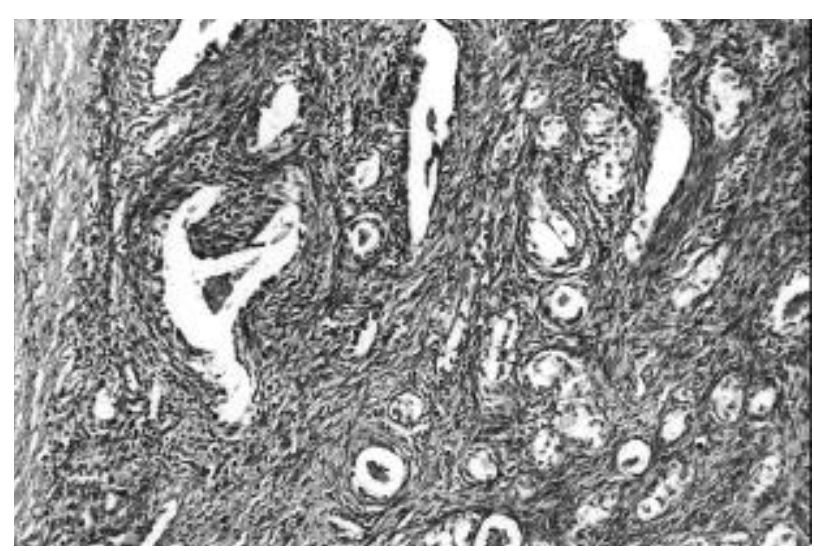

Figure 2. Biphasic pattern consisting of glandular structures and spindle cell component (HEx310)
(Novacastra; antigen retrieval;1/800, $60 \mathrm{~min}$ ), S-100 (Neomarker; antigen retrieval, 1/100, 60min); Ki-67 (Novacastra, antigen retrieval, 1/100, $60 \mathrm{~min}$ ), p53 (Novacastra, antigen retrieval, 1/40, $60 \mathrm{~min}$ ).

The epithelial component was positive for pancytokeratin (Figure 3) and EMA. Scattered spindle cells were also stained by cytokeratin antibody. Spindle cells were diffusely immunreactive to vimentin antibody. S-100 protein was negative. Ki-67(MIB-1) proliferation index was $30 \%$. Twenty five percent of the nuclei were immunoreactive to anti-p53 antibody.

\section{Discussion}

Synovial sarcoma accounts for $5-10 \%$ of all soft tissue sarcomas. $^{3,16,19}$ More than $80 \%$ of cases occur in the extremities. Head and neck is a rare (3-9\%), but well known location of synovial sarcoma. ${ }^{2,3,19}$ About ten cases of primary laryngeal synovial sarcoma were reported (Table 1). We present a 24 years old male patient with a supraglottic tumor, measuring $4.5 \mathrm{~cm}$ and involving the aryepiglottic plica as in the most of the reported cases. The patients age is typical for synovial sarcoma, which is a tumor of young adults.

Primary tumors of larynx are predominantly squamous cell carcinoma. ${ }^{2}$ Other unusual tumors in this location are fibrosarcoma, chondrosarcoma, osteosarcoma and rhabdomyosarcoma. ${ }^{4,5}$ Carcinosarcoma of larynx is a composite tumor consisting of carcinomatous and sarcomatous areas; which was described by some authors in other names.

The term carcinosarcoma is applied when heterologous elements such as bone, cartilage or muscle are encountered in a tumor, that elsewhere shows one of the more convential patterns of carcinoma. In carcinosarcoma the patient is often in his late middle age with a long history of tobacco use. The tumor is polypoid and often ulcerated. The carci-

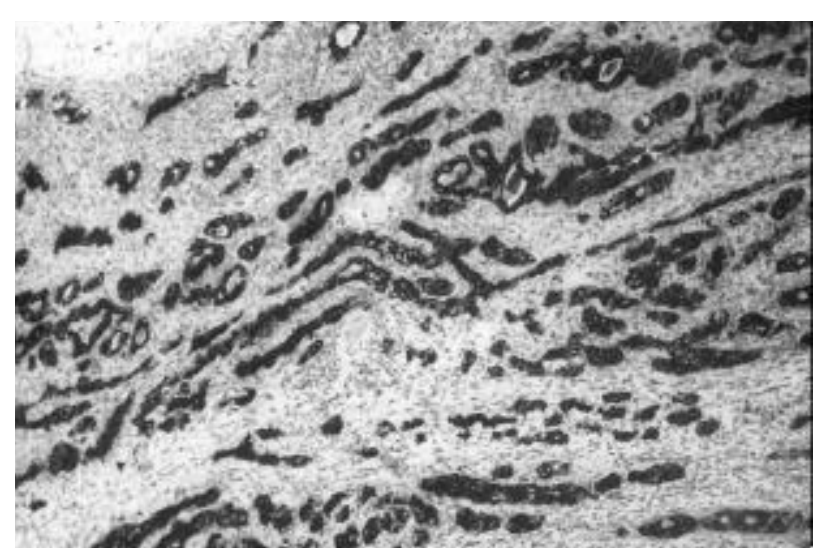

Figure 3. Pancytokeratin positivity in the glandular component (immunoperoxidase $x$ 125) 
nomatous element is usually a squamous cell carcinoma. Although the morphogenesis of carcinosarcoma remains controversial, it is suggested that the sarcomatous part seems to be a transformation of the epithelial component. Immunohistochemistry and electron microscopy support the view that carcinosarcoma is basically an epithelial tumour that shows varying degrees of mesenchymal differentiation. ${ }^{1,3,8,18}$ In contrast, synovial sarcoma occurs predominantly in young adults. The mucosa coating the neoplasm is usually intact. Squamous metaplasia is very rare. Microscopic examination of the tumor in the presented case revealed a biphasic tumor beneath an intact epithelium. The mesenchymal component consisted of spindle cells. Osteosarcomatous, chondrosarcomatous or rhabdomyosarcomatous differentiation were not observed.

Biphasic synovial sarcoma causes few problems in diagnosis but synovial sarcoma can display different patterns. The monophasic fibrous type can be misdiagnosed as a spindle cell sarcoma or a hemangiopericytoma. ${ }^{1,3,19}$ The pure epithelial subtype can be confused with a carcinoma. ${ }^{1-3,19}$ The poorly differentiated subtype has morphological similarities to small round cell tumors. CD99 antigen

Table 1. Endolaryngeal synovial sarcomas: reported cases

\begin{tabular}{|c|c|c|c|c|}
\hline Reference & Age/sex & Location & Therapy & Follow-up \\
\hline Miller & $23 / \mathrm{F}$ & interarytenoid and left arytenoid & $\begin{array}{l}\text { excision; supraglottic laryngectomy } \\
\text { and total laryngectomy }\end{array}$ & NED after 12 years \\
\hline Gatti & \multicolumn{4}{|c|}{ same case as above reported by Miller } \\
\hline Geahchan & $24 / \mathrm{M}$ & $\begin{array}{l}\text { left arytenoid and left epiglottic } \\
\text { fold }\end{array}$ & $\begin{array}{l}\text { partial pharyngectomy, total } \\
\text { laryngectomy }\end{array}$ & $\begin{array}{l}\text { recurrence } 4 \text { years } \\
\text { after surgery; lung } \\
\text { metastasis after } \\
6 \text { years }\end{array}$ \\
\hline
\end{tabular}

\begin{tabular}{|c|c|c|c|c|}
\hline Quinn & $76 / \mathrm{M}$ & right subglottic area & hemilaryngectomy & NED after 3 years \\
\hline Kitsmaniuk & $15 / \mathrm{M}$ & $\begin{array}{l}\text { left arytenoid; pyriform sinus, } \\
\text { epiglottis, true and false cords }\end{array}$ & extended total laryngectomy & NED after 8 months \\
\hline Kleinasser & $58 / \mathrm{F}$ & subglottic area & partial resection & $\begin{array}{l}\text { recurrence after } \\
7 \text { years }\end{array}$ \\
\hline Pruszczynski & $28 / \mathrm{F}$ & $\begin{array}{l}\text { left aryepiglottic fold and false } \\
\text { vocal cord }\end{array}$ & local excision, RT (66Gy) & NED after 3 years \\
\hline Ferlito & $28 / \mathrm{M}$ & right aryepiglottic fold, epiglottis & $\begin{array}{l}\text { Preop. RT(25Gy), supraglottic } \\
\text { laryngectomy, right neck dissection, } \\
\text { postop. RT( } 50 \mathrm{~Gy})\end{array}$ & NED after 16 years \\
\hline Danninger & $53 / \mathrm{M}$ & right aryepiglottic fold & $\begin{array}{l}\text { laryngectomy, neck dissection } \\
\text { RT(64Gy) }\end{array}$ & $\begin{array}{l}\text { NED after } 16 \\
\text { months }\end{array}$ \\
\hline Morland & $14 \mathrm{M}$ & left arytenoid & $\begin{array}{l}\text { excision, laryngectomy following } \\
\text { recurrence, CT and } \mathrm{RT}(60 \mathrm{~Gy})\end{array}$ & $\begin{array}{l}\text { recurrence after } \\
3 \text { years } \\
\text { NED after } 10 \text { months }\end{array}$ \\
\hline \multirow[t]{2}{*}{ Dei Tos } & $27 \mathrm{M}$ & right aryepiglottic fold & $\begin{array}{l}\text { excision, hemilaryngectomy } \\
\text { following recurrence, } \\
\text { CT and RT(62Gy) }\end{array}$ & $\begin{array}{l}\text { recurrence after } \\
3 \text { months }\end{array}$ \\
\hline & & & & NED after 9 months \\
\hline Present case & $24 / \mathrm{M}$ & $\begin{array}{l}\text { left aryepiglottic fold, epiglottis } \\
\text { and left arytenoid }\end{array}$ & $\begin{array}{l}\text { excision, hemilaryngectomy, total } \\
\text { laryngectomy, neck dissection, } \\
\text { RT( } 45 G y) \text { and CT }\end{array}$ & $\begin{array}{l}\text { Recurrence after } \\
1 \text { year } \\
\text { Lung metastasis } \\
\text { after } 20 \text { months } \\
\text { Alive and NED at } 3.5 \\
\text { years }\end{array}$ \\
\hline
\end{tabular}

RT: Radiotherapy CT: Chemotherapy 
is positive in 95\% of Ewing's sarcoma/PNET family tumors; a synovial sarcoma can also be immunoreactive to anti-CD99 antibody. ${ }^{3}$ Extensive sampling of the tumor and immunohistochemistry are helpful in the differential diagnosis. Cytogenetic analysis is also important in the differential diagnosis, because of the typical $(x ; 18)$ translocation of synovial sarcoma.

Various prognostic factors have been accepted in synovial sarcoma including age, location, size of the tumor, necrosis, high mitotic index. ${ }^{16,19}$ New studies have indicated several other possible prognostic parameters. A Ki-67 index of $10 \%$ or more was considered highly proliferative. ${ }^{17}$ Our case showed a Ki-67 index of $30 \%$. The significance of p53 immunostaining is not clear, but in a study of 34 synovial sarcoma cases it was suggested that the overall survival was significantly reduced in patients having synovial sarcoma with p53 alterations (cut off value: $10 \%) .{ }^{15}$ We found that $25 \%$ of nuclei were immunreactive to $\mathrm{p} 53$ antibody. Our patient was therefore in a poor prognostic group concerning his age, tumor size, Ki-67 index and p53 positivity.

Surgery is the main therapy for synovial sarcoma and is often supplemented with radiotherapy., ${ }^{2,16,19}$ Local recurrences of up to $80 \%$ have been recorded after inadequate surgery without radiotherapy. ${ }^{16}$ Lymph node dissection is not necessary in most cases. ${ }^{2,3}$ Because of a local recurrence and a palpable mass in the neck region of the presented case, neck dissection was performed, but the lymph nodes showed no infiltration. The cases shown in Table 1 were all treated with surgery. In some of them radiotherapy was added. Only two cases underwent chemotherapy to whom ifosfamide was given in high doses. ${ }^{3,12}$ In our case a chemotherapy consisting of ifosfamide and adriamycin were applied. The therapy was effective and the metastatic nodules disappeared.

We add a new case of laryngeal synovial sarcoma to the literature. Ifosfamide seems to be effective even in the metastatic disease. Because of the limited number of the laryngeal cases, every new case will bring some new information about the therapy.

\section{References}

1. Aubert S: Parapharyngeal synovial sarcoma. Ann Pathol 21: 71-75, 2001

2. Danninger $R$, Hurner $U$, Stammberger $H$ : Das Synovialsarkom, ein seltener Tumor des Larynx. Falldarstellung und differentialdiagnostische Überlegungen. Laryngorhinootologie 73: 442-444, 1994

3. Dei Tos A, Dal Cin P, Sciot R, et al: Ann Otol Rhinol Laryngol 107: 1080-1085, 1998

4. Ferlito A, Caruso $G$ : Endolaryngeal synovial sarcoma: An update on diagnosis and treatment. ORL, J Otorhinolaryngol Relat Spec 53: 116-119, 1991

5. Garenstein A, Neel HB $3^{\text {rd }}$, Weiland LH, et al: Sarcomas of the larynx. Arch Otolaryngol 106: 8-12, 1980

6. Gatti WM, Strom CG, Orfei E: Synovial sarcoma of the laryngopharynx. Arch Otolaryngol 101: 633-636, 1975

7. Geahchan NE, Lambert J, Micheau C, et al: Synovialome malin du larynx. Ann Otolaryngol Chir Cervicofac 100: 61-65, 1983

8. Ianniello F, Ferri E, Armato E, et al: Carcinosarcoma of the larynx: immunohistochemical study, clinical considerations, therapeutic strategies. Acta Otorhinolaryngol Ital 21: 192-197, 2001

9. Kitsmaniuk ZD, Volkov I, Demochko VB, et al: Synovial sarcoma of the larynx. Vestn Otorinolaryngol; 2: 61-62, 1985

10. Kleinasser $O:$ Tumors of the larynx and hypopharynx. Stuttgart Thieme 1988: pp 326-328

11. Miller LH, Santaella-Latimer L, Miller T: Synovial sarcoma of the larynx. Trans Am Acad Ophtalmol Otolaryngol 80: 448451, 1975

12. Morland B, Cox $G$, Randall $C$, et al: Synovial sarcoma of the larynx in a child: case report and histological appearances. Med Pediatr Oncol 23: 64-68, 1994

13. Pruszczynski M, Manni JJ, Smedt F: Endolaryngeal synovial sarcoma: Case report with immunohistochemical studies. Head Neck 11: 76-80, 1989

14. Quinn HJ: Synovial sarcoma of the larynx treated by partial laryngectomy. Laryngoscope 94: 1158-1161, 1984

15. Schneider-Stock $R$, Onnasch D, Haeckel C, et al: Prognostic significance of p53 gene mutations and p53 protein expression in synovial sarcoma. Virchows Arch 435: 407-412, 1999

16. Skytting B: Synovial sarcoma: A Scandinavian Sarcoma Group Project. Acta Orthopaedica Scandinavia. Supplementum 291: $1-28,2000$

17. Skytting BT, Bauer HC, Perfekt $R$, et al: $\mathrm{Ki}-67$ is stongly prognostic in synovial sarcoma; analysis based on 86 patients from the Scandinavian Sarcoma Group Register. Br J Cancer 80: 1809-1814, 1999

18. Thompson LD: Diagnostically challenging lesions in head and neck pathology. Eur Arch Otorhinolaryngol 254: 357-366, 1997

19. Weiss SW, Goldblum JR: Malignant soft tissue tumors of uncertain type. In: Enzinger and Weiss's Soft Tissue Tumors, $4^{\text {th }}$ ed. Mosby St Louis 2001 